\title{
Diversity and distribution of Brachionidae (Rotifera) in Thailand, with a key to the species
}

\author{
Sujeephon ATHIBAI, ${ }^{1}$ Hendrik SEGERS, ${ }^{2}$ La-orsri SANOAMUANG ${ }^{1,3 *}$ \\ ${ }^{1}$ Applied Taxonomic Research Center, Department of Biology, Faculty of Science, Khon Kaen University, Khon Kaen 40002, Thai- \\ land; ${ }^{2}$ Freshwater Laboratory, Royal Belgian Institute of Natural Sciences, Vautierstraat 29, 1000 Brussels, Belgium; ${ }^{3}$ Faculty of Sci- \\ ence, Mahasarakham University, Maha Sarakham 44150, Thailand \\ *Corresponding author: la_orsri@kku.ac.th
}

\begin{abstract}
We investigated the diversity of brachionid rotifers in Thailand. Rotifers were collected from a wide range of habitat types (294 sites, 508 samples) including canals, lakes, peat swamps, ponds, reservoirs, rice fields, rivers, swamps and temporary ponds from April 1998 to January 2004. Twenty-eight species including 11 infrasubspecific forms belonging to five genera were identified. The most frequently encountered species was Brachionus falcatus (50.7\% of the sampling sites), followed by Keratella cochlearis (50\%), B. angularis $(49.7 \%)$, K. tropica (46.3\%) and B. forficula (45.9\%). Less frequently encountered species were B. caudatus, B. durgae and B. urceolaris. These species were found in low abundances and only in a single site. Two sites in the Northeast - Nong Changpeuak and Bueng Srithat - recorded the greatest richness with 15 taxa, whereas no brachionid rotifers were found in 31 sites. On average, the species richness was five taxa per sampling site. A key to the genera and species of Thai brachionid rotifers is provided.
\end{abstract}

Key words: biodiversity, Brachionus, Keratella, rotifers, Southeast Asia.

Received: January 2013. Accepted: June 2013.

\section{INTRODUCTION}

Rotifera of the family Brachionidae are amongst the most well-studied rotifer groups. This is largely due to their ecological and economic relevance (Segers, 2008). The most well known are the brackish water species of the $\mathrm{Bra}$ chionus plicatilis complex, which are important as a primary live food source for commercial fish and shrimp larvae, and are therefore extensively used in aquaculture (Lubzens et al., 2001). Moreover, three freshwater species, B. calyciflorus, B. rubens and B. urceolaris, are particularly suited as test organisms for ecotoxicological studies (Snell and Janssen, 1995). The common occurrence of phenotypic plasticity resulting in polymorphism has confounded the taxonomy of brachionid rotifers (Nogrady et al., 1993). The most striking examples of phenotypic plasticity occurs in Brachionus and Keratella. For example, Keratella cochlearis and K.tropica are notoriously variable morphologically (Hofmann, 1980; Marinone and Zagarese, 1991). There are several factors that affect rotifer phenotypic plasticity. These include temperature (Bielanska-Grajner, 1995) and, especially, presence of predators (Marinone and Zagarese, 1991). Different morphological variants of species have been treated as infrasubspecific varieties or forms (Nogrady et al., 1993). However, there is cryptic diversity in the genus Brachionus. For instance, a re-examination of existing available names proposed B. plicatilis and $B$. rotundiformis as the correct names for the $L$ - and $S$-types of
B. plicatilis, respectively (Segers, 1995), and more species are being distinguished in the $B$. plicatilis complex (CirosPérez et al., 2001) as well as in other taxa in the genus Brachionus (Gilbert and Walsh, 2005; Xiang et al., 2010, 2011a, 2011b).

During the past decades, there has been a steady increase in interest in rotifer fauna in Thailand. However, information on Thai rotifers is still incomplete and there is a strong need to increase our knowledge on the subject. This also holds for the family Brachionidae. Recently, 169 species belonging to seven genera: Anuraeopsis, Brachionus, Kellicottia, Keratella, Notholca, Plationus and Platyias have been listed as making up the Brachionidae (Segers, 2007, 2008). Among these genera, Brachionus is the most diverse genus, containing 64 species and contributing the second most number of species to rotifer diversity in Southeast (SE) Asia (Segers, 2001). Thai brachionid rotifers have been recorded in a number of publications (Boonsom, 1984; Sanoamuang et al., 1995; Chittapun and Pholpunthin, 2001; Sanoamuang and Savatenalinton, 2001; Segers et al., 2004; Chittapun et al., 2007). Most studies have focused on the northeastern and southern parts of the country while few records are available from other regions. Considering the economic and ecological importance of the family Brachionidae in tropical and SE Asian waters, we provide a review of the taxonomy and distribution of this family in Thai waters. In addition, keys to the genera and species of Thai bra- 
chionid rotifers were constructed based on external morphology, and illustrations were provided.

\section{METHODS}

\section{Sample collection and examination}

Rotifers were collected from a wide range of habitats (294 sites, 508 samples) including canals, lakes, peat swamps, ponds, reservoirs, rice fields, rivers, swamps and temporary ponds. Horizontal tows were made at a depth of $2 \mathrm{~m}$ with an approximate linear distance of $5 \mathrm{~m}$ in open water using a $30-\mu \mathrm{m}$ mesh size plankton net. In each site, sampling was performed in both dry and rainy seasons from April 1998 to January 2004. However, sampling was done only once in 80 sites. Samples were preserved in 5\% formaldehyde-solution. Locations of the sampling sites are shown in Fig. 1. Water temperature, conductivity, $\mathrm{pH}$, dissolved oxygen (DO), turbidity and salinity were measured at each locality using a Horiba Water Quality Checker (U10; Horiba Ltd., Fukuoka, Japan). Brachionid rotifers were examined under an Olympus $\mathrm{CH}-10$ compound microscope at 400-1000× (Olympus, Tokyo, Japan). The rotifers were identified to species level using the keys and publications from several taxonomists (Ahlstrom, 1940; 1943; Koste, 1978; Koste and Shiel, 1987). Drawings were made using an Olympus CH-10 microscope (Olympus) equipped with a drawing tube. The specimens were prepared for observation with a scanning electron microscopy (SEM) (SEMLEO 1450) using the critical point drying technique described in earlier publications (Sanoamuang and McKenzie, 1993; Segers, 1993; Segers and Dumont, 1993). In order to analyse the relationship between the environmental variables and species data, canonical correspondence analysis (CCA) was performed with the PC-ORD statistical software programme (version 4; MjM Software Design, Geleneden Beach, OR, USA).The CCA procedure produces an ordination diagram in which species are represented by points and environmental variables by vectors. A set of environmental variables and species composition were tested for significance of relevant trends by the Monte Carlo permutation test.

\section{RESULTS AND DISCUSSION}

\section{Species composition of Thai brachionid rotifers}

A total of 39 taxa, 28 species and 11 infrasubspecific forms of the family Brachionidae were recorded. A list of the identified brachionid rotifers, their distribution and characteristics of their habitats is shown in Tab. 1. Description of sampling sites and variables measured at the sampling sites are presented in Supplementary Tab. 1. The most diverse genus of Thai Brachionidae is Brachionus, comprising 18 species and 10 infrasubspecific forms, followed by Keratella (6 species and 1 infrasubspecific form), Anuraeopsis (2 species), Plationus and Platyias. The two last genera contained only a single species each.This concurs with Segers (2008), who reported that Brachionus is the most diverse genus of the family Brachionidae in the world (64 species) (Segers 2007, SilvaBriano et al., 2007). Most of the species recorded from Thailand are common and widely distributed. On average, species richness was five taxa per site. Two sites in the northeastern area (Nong Changpeuak and Bueng Srithat) had the greatest richness with 15 taxa; whereas, no brachionid rotifers were found in 31 sites. The most frequently encountered species were Brachionus falcatus (in $50.7 \%$ of samplings), followed by Keratella cochlearis (50\%), B. angularis (49.7\%), K. tropica (46.3\%) and B. forficula (45.9\%). Species with low frequencies were $B$. caudatus, $B$. durgae and $B$. urceolaris. These species were only found, as a few specimens, in a single site.

\section{Distribution of Thai brachionid rotifers}

Thirteen of the Thai brachionid taxa are widely distributed throughout Thailand (northern, northeastern, central and southern regions) as shown in Tab. 1. Six taxa are found to have a restricted distribution: $B$. angularis $\mathrm{f}$. bidens and $B$. forficula $\mathrm{f}$. minor are recorded only from the North; B. caudatus, B. durgae and B. urceolaris occur only in Central Thailand; and $K$. edmondsoni is recorded only from the Northeast. It is noteworthy that the following eight species, reported by previous authors (Sanoamuang et al., 1995; Chittapun and Pholpunthin, 2001; Segers et al., 2004) were not recorded here, probably due to their rarity and restricted distribution: $A n u-$ raeopsis navicula, Brachionus kostei, B. lyratus, B. sessilis, B. srisumonae, B. variabilis, Keratella javana and $K$. taksinensis. These include the two SE Asian brachionid endemics: B. srisumonae, known from the northeastern region and Laos, and $K$. taksinensis, from the South.

\section{Relationship between rotifer diversity and habitat characteristics}

The greatest diversity of brachionid rotifers was in ponds and rivers (30 taxa), followed by canals ( 27 taxa) and swamps (25 taxa). All the habitats having higher rotifer diversity were permanent water bodies, whereas temporary water bodies (i.e. rice fields and temporary ponds) were inhabited by relatively few (14) taxa. This result concurs with the report on the brachionid fauna of Northeastern Thailand, where 32 brachionid rotifers were encountered in permanent waters bodies and only five species were recorded from temporary ponds (basins) (Sanoamuang et al., 1995). In peat swamps, characterised by acidic and brownish water, only a few species could be found. For example, Chittapun and Pholpunthin (2001) 


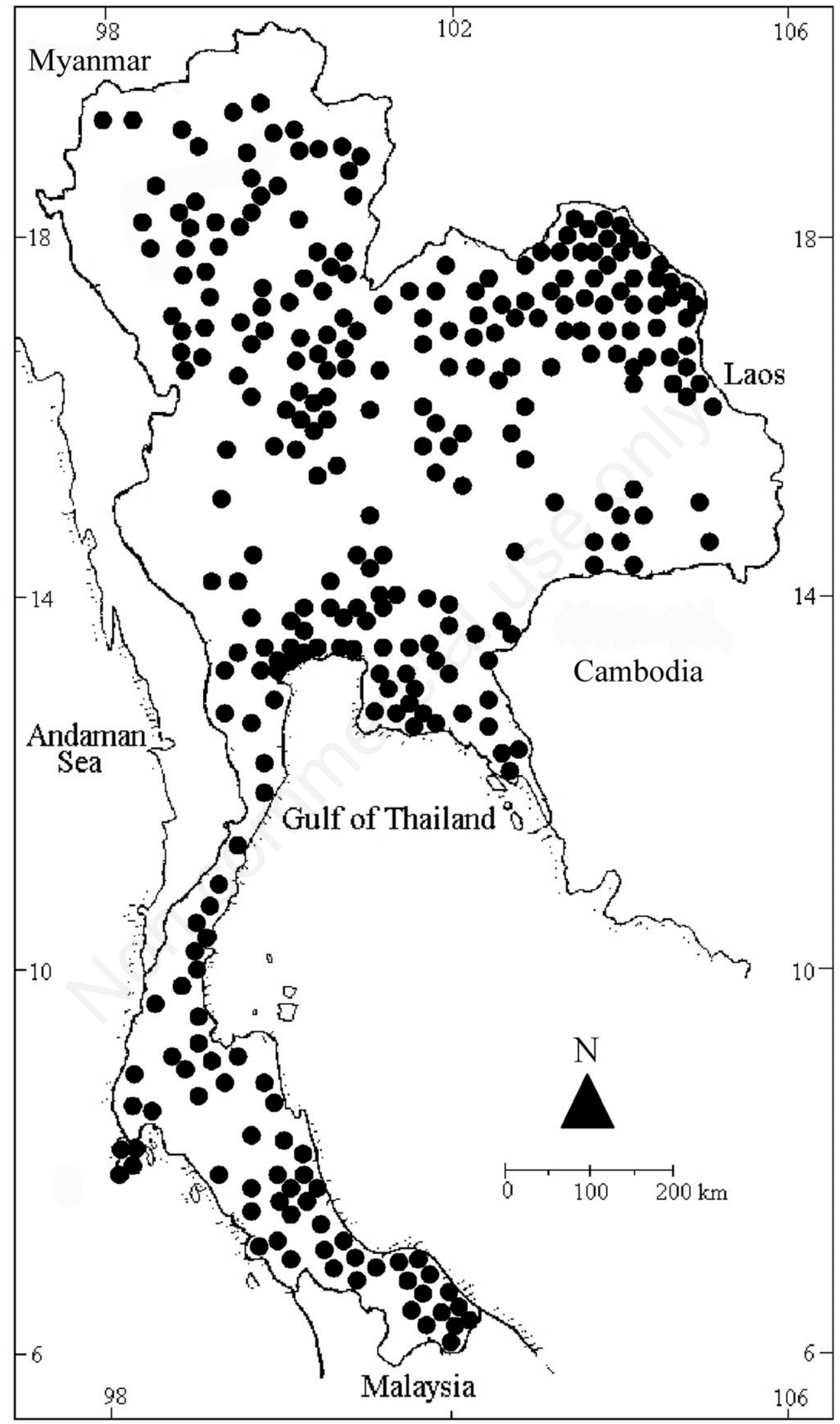

Fig. 1. Map of Thailand showing location of sampling sites (black spots). 
investigated the rotifer fauna in three acidic peat swamps (pH 4.30-6.37) in Southern Thailand. A total of 93 rotifer species were recorded, only four of which were brachionids: Anuraeopsis fissa, Brachionus quadridentatus $\mathrm{f}$. mirabilis, Keratella javana and Plationus patulus. These results agree with the observation that Brachionus rotifers are generally absent from acidic waters (Ahlstrom, 1940). Another environmental variable that influences the distribution of rotifers is salinity: no brachionid rotifers were found in estuaries. Only one species, B. rotundiformis, has been found in salinities ranging from 0.04 to 2.73 practi- cal salinity units (PSU). This result agrees with previous work that indicated that rotifer communities are limited by salinity (Ruttner-Kolisko, 1974) and that rotifer biodiversity decreases with increasing water salinity (Sladecek, 1983). Attayde and Bozelli (1998) also reported that the species diversity of rotifers decreased with increasing marine influence. On the other hand, species richness of rotifers in Turkish continental waters was significantly increased with salinity in sub-saline waters between 1000 and $6000 \mu \mathrm{S} \mathrm{cm}^{-1}$ (Kaya et al., 2010). In addition, the family does contain an important number of brackish-

Tab. 1. List of brachionid rotifers recorded in Thailand during this study.

\begin{tabular}{|c|c|c|}
\hline Species & Habitat & Distribution area \\
\hline Anuraeopsiscoelata (De Beauchamp, 1932) & $\mathrm{Ca}, \mathrm{L}, \mathrm{P}, \mathrm{Re}, \mathrm{Ri}, \mathrm{Sw}$ & $\mathrm{N}, \mathrm{NE}, \mathrm{C}, \mathrm{S}$ \\
\hline A. fissa (Gosse, 1851) & $\mathrm{Ca}, \mathrm{P}, \mathrm{Ps}, \mathrm{Re}, \mathrm{Rf}, \mathrm{Ri}, \mathrm{Sw}, \mathrm{T}$ & $\mathrm{N}, \mathrm{NE}, \mathrm{C}, \mathrm{S}$ \\
\hline Brachionus angularis Gosse, 1851 & $\mathrm{Ca}, \mathrm{L}, \mathrm{P}, \mathrm{Re}, \mathrm{Rf}, \mathrm{Ri}, \mathrm{Sw}, \mathrm{T}$ & $\mathrm{N}, \mathrm{NE}, \mathrm{C}, \mathrm{S}$ \\
\hline B. angularis f. bidens Plate, 1886 & $\mathrm{Ri}$ & $\mathrm{N}$ \\
\hline B. bennini (Leissling, 1924) & $\mathrm{P}, \mathrm{Ri}$ & $\mathrm{N}, \mathrm{NE}$ \\
\hline B. bidentatus f. inermis (Rousselet, 1906) & $\mathrm{P}, \mathrm{Re}, \mathrm{Ri}, \mathrm{Sw}$ & $\mathrm{N}, \mathrm{NE}, \mathrm{C}$ \\
\hline B. budapestinensis Daday, 1885 & $\mathrm{P}, \mathrm{Re}$ & $\mathrm{NE}, \mathrm{C}$ \\
\hline B. calyciflorus Pallas, 1766 & $\mathrm{Ca}, \mathrm{P}, \mathrm{Ps}, \mathrm{Re}, \mathrm{Ri}, \mathrm{Sw}$ & $\mathrm{N}, \mathrm{NE}, \mathrm{C}, \mathrm{S}$ \\
\hline B. calyciflorus f. amphiceros Ehrenberg, 1838 & $\mathrm{Ca}, \mathrm{L}, \mathrm{P}, \mathrm{Ri}$ & $\mathrm{N}, \mathrm{NE}, \mathrm{C}$ \\
\hline B. calyciflorus f. anuraeiformis Brehm, 1909 & $\mathrm{Ca}, \mathrm{L}, \mathrm{P}, \mathrm{Re}, \mathrm{Rf}, \mathrm{Ri}, \mathrm{Sw}$ & $\mathrm{N}, \mathrm{NE}, \mathrm{C}, \mathrm{S}$ \\
\hline B. caudatus Barrois and Daday, 1894 & $\mathrm{Re}$ & $\mathrm{C}$ \\
\hline B. caudatus f. aculeatus Hauer, 1937 & $\mathrm{Ri}, \mathrm{Sw}$ & $\mathrm{N}, \mathrm{NE}, \mathrm{C}$ \\
\hline B. caudatus f. apsteini Fadeew, 1925 & $\mathrm{Ca}, \mathrm{P}, \mathrm{Re}, \mathrm{Ri}, \mathrm{Sw}$ & $\mathrm{N}, \mathrm{NE}, \mathrm{C}$ \\
\hline B. dichotomus f. reductus Koste and Shiel, 1980 & $\mathrm{Ca}, \mathrm{P}, \mathrm{Re}, \mathrm{Sw}$ & $\mathrm{N}, \mathrm{NE}, \mathrm{C}$ \\
\hline B. diversicornis (Daday, 1883) & $\mathrm{Ca}, \mathrm{L}, \mathrm{P}, \mathrm{Re}, \mathrm{Ri}, \mathrm{Sw}$ & $\mathrm{N}, \mathrm{NE}, \mathrm{C}$ \\
\hline B. donneri Brehm, 1951 & $\mathrm{Ca}, \mathrm{L}, \mathrm{P}, \mathrm{Re}, \mathrm{Ri}, \mathrm{Sw}$ & $\mathrm{N}, \mathrm{NE}, \mathrm{C}$ \\
\hline B. durgae Dhanapathi, 1974 & $\mathrm{P}$ & $\mathrm{C}$ \\
\hline B. falcatus Zacharias, 1898 & Ca, L, P, Ps, Re, Rf, Ri, Sw, T & $\mathrm{N}, \mathrm{NE}, \mathrm{C}, \mathrm{S}$ \\
\hline B. forficula Wierzejski, 1891 & $\mathrm{Ca}, \mathrm{L}, \mathrm{P}, \mathrm{Ps}, \mathrm{Re}, \mathrm{Ri}, \mathrm{Sw}, \mathrm{T}$ & N, NE, C, S \\
\hline B. forficula f. minor Voronkov, 1913 & $\mathrm{Ri}, \mathrm{Sw}$ & $\mathrm{N}$ \\
\hline B. murphyi Sudzuki, 1989 & $\mathrm{Ca}, \mathrm{Rf}$ & $\mathrm{N}, \mathrm{NE}$ \\
\hline B. nilsoni Ahlstrom, 1940 & $\mathrm{~L}, \mathrm{Ri}$ & $\mathrm{N}, \mathrm{C}$ \\
\hline B. quadridentatus Hermann, 1783 & $\mathrm{Ca}, \mathrm{L}, \mathrm{P}, \mathrm{Re}, \mathrm{Rf}, \mathrm{Ri}, \mathrm{Sw}$ & $\mathrm{N}, \mathrm{NE}, \mathrm{C}, \mathrm{S}$ \\
\hline B. quadridentatus f. brevispinus Ehrenberg, 1832 & $\mathrm{Ca}, \mathrm{P}, \mathrm{Re}, \mathrm{Ri}$ & $\mathrm{N}, \mathrm{NE}, \mathrm{C}$ \\
\hline B. quadridentatus f. cluniorbicularis Skorikov, 1894 & Rf, Ri & $\mathrm{N}, \mathrm{NE}, \mathrm{C}$ \\
\hline B. quadridentatus f. melhemi (Barrois and Daday, 1894) & $\mathrm{P}, \mathrm{Ri}$ & $\mathrm{N}, \mathrm{C}, \mathrm{S}$ \\
\hline B. quadridentatus f. mirabilis (Daday, 1897) & $\mathrm{Ca}, \mathrm{P}, \mathrm{Rf}$ & $\mathrm{N}, \mathrm{S}$ \\
\hline B. rotundiformis Tschugunoff, 1921 & $\mathrm{Ca}, \mathrm{P}, \mathrm{Ps}, \mathrm{Ri}$ & $\mathrm{NE}, \mathrm{C}, \mathrm{S}$ \\
\hline B. rubens Ehrenberg, 1838 & $\mathrm{Ca}, \mathrm{P}, \mathrm{Re}, \mathrm{Rf}, \mathrm{Ri}$ & $\mathrm{N}, \mathrm{NE}, \mathrm{C}$ \\
\hline B. urceolaris (Müller, 1773) & $\mathrm{Ca}$ & $\mathrm{C}$ \\
\hline Keratella cochlearis (Gosse, 1851) & $\mathrm{Ca}, \mathrm{L}, \mathrm{P}, \mathrm{Re}, \mathrm{Rf}, \mathrm{Ri}, \mathrm{Sw}$ & $\mathrm{N}, \mathrm{NE}, \mathrm{C}, \mathrm{S}$ \\
\hline K. edmondsoni (Ahlstrom, 1943) & $\mathrm{Ca}, \mathrm{L}, \mathrm{P}, \mathrm{Re}, \mathrm{Sw}$ & $\mathrm{NE}$ \\
\hline K. lenzi Hauer, 1953 & $\mathrm{Ca}, \mathrm{L}, \mathrm{P}, \mathrm{Re}, \mathrm{Ri}, \mathrm{Sw}$ & $\mathrm{N}, \mathrm{NE}, \mathrm{C}, \mathrm{S}$ \\
\hline K. lenzi f. heliaca Bērziņš, 1955 & L, P, Re, Ri, Sw & $\mathrm{N}, \mathrm{NE}, \mathrm{C}$ \\
\hline K. procurva $($ Thorpe, 1891$)$ & $\mathrm{Ca}, \mathrm{Sw}$ & $\mathrm{N}, \mathrm{NE}, \mathrm{C}$ \\
\hline K. tecta (Gosse, 1851) & $\mathrm{Ca}, \mathrm{L}, \mathrm{P}, \mathrm{Re}, \mathrm{Ri}, \mathrm{Sw}$ & $\mathrm{N}, \mathrm{NE}, \mathrm{C}$ \\
\hline K. tropica (Apstein, 1907) & $\mathrm{Ca}, \mathrm{L}, \mathrm{P}, \mathrm{Ps}, \mathrm{Re}, \mathrm{Rf}, \mathrm{Ri}, \mathrm{Sw}, \mathrm{T}$ & $\mathrm{N}, \mathrm{NE}, \mathrm{C}, \mathrm{S}$ \\
\hline Plationus patulus (Müller, 1786) & $\mathrm{Ca}, \mathrm{L}, \mathrm{P}, \mathrm{Ps}, \mathrm{Re}, \mathrm{Rf}, \mathrm{Ri}, \mathrm{Sw}$ & $\mathrm{N}, \mathrm{NE}, \mathrm{C}, \mathrm{S}$ \\
\hline Platyias quadricornis (Ehrenberg, 1832) & Ca, P, Ps, Re, Rf, Ri, Sw & $\mathrm{N}, \mathrm{NE}, \mathrm{C}, \mathrm{S}$ \\
\hline
\end{tabular}

Ca, canal; L, lake; P, pond; Re, reservoir; Ri, river; Sw, swamp; N, North; NE, Northeast; C, Central; S, South; Ps, peat swamp; Rf, rice field; T, temporary pond. 
water or even marine taxa, especially in Keratella (Segers and De Smet, 2008; Fontaneto et al., 2008).

The diversity of brachionid rotifers in lentic ecosystems (lakes, peat swamps, ponds, reservoirs, rice fields, swamps and temporary ponds, $\mathrm{n}=37$ taxa) was higher than in lotic ecosystems (canals and rivers, $\mathrm{n}=32$ taxa). Two taxa, $\mathrm{Bra}$ chionus angularis $\mathrm{f}$. bidens and $B$. caudatus, were found only in lotic ecosystems, while $B$. durgae, $B$. murphyi, $B$. urceolaris, Keratella edmondsoni and K. procurva were recorded only from lentic ecosystems. This result supports earlier studies indicating that Brachionus are planktonic rather than periphytic or benthic animals, although there are notorious exceptions, e.g. B. quadridentatus (Pejler and Bērziñš, 1989). The most eurytopic brachionid rotifers were B. angularis (9 habitat types), K. tropica (9 habitat types) and B. forficula and B. falcatus (8 habitat types). Four taxa were found in distinct habitat types: $B$. angularis $\mathrm{f}$. bidens occurred in rivers, $B$. caudatus inhabited a canal, $B$. durgae and $B$. urceolaris were restricted to ponds.
During the rainy season, diversity of the brachionid rotifers was higher than during the dry season. Two species (Brachionus budapestinensis and B. murphyi) were found only during the dry season whereas four species and two infrasubspecific forms (B. angularis f. bidens, B. bennini, B. caudatus, B. durgae, B. forficula f. minor and B. urceolaris) were recorded only during the rainy season.

Results of CCA indicate that most of the variation in environmental variables (11.9\%) is explained in the first axis (eigen value $=0.479$ ). Correlation between the first axis and species-environmental variables was 0.857 . The second axis (eigen value $=0.067$ ) accounted for $1.7 \%$ of the variation in the data set. Correlation between the second axis and species-environmental variables was 0.419 . The species and their abundance were significantly correlated with three environmental variables: temperature (inter-set correlation $=0.42$ ), conductivity (inter-set correlation $=0.76$ ) and salinity (inter-set correlation $=0.85$ ) (Monte Carlo test, $\mathrm{P}=0.01$ ). The two latter variables seem

CCA

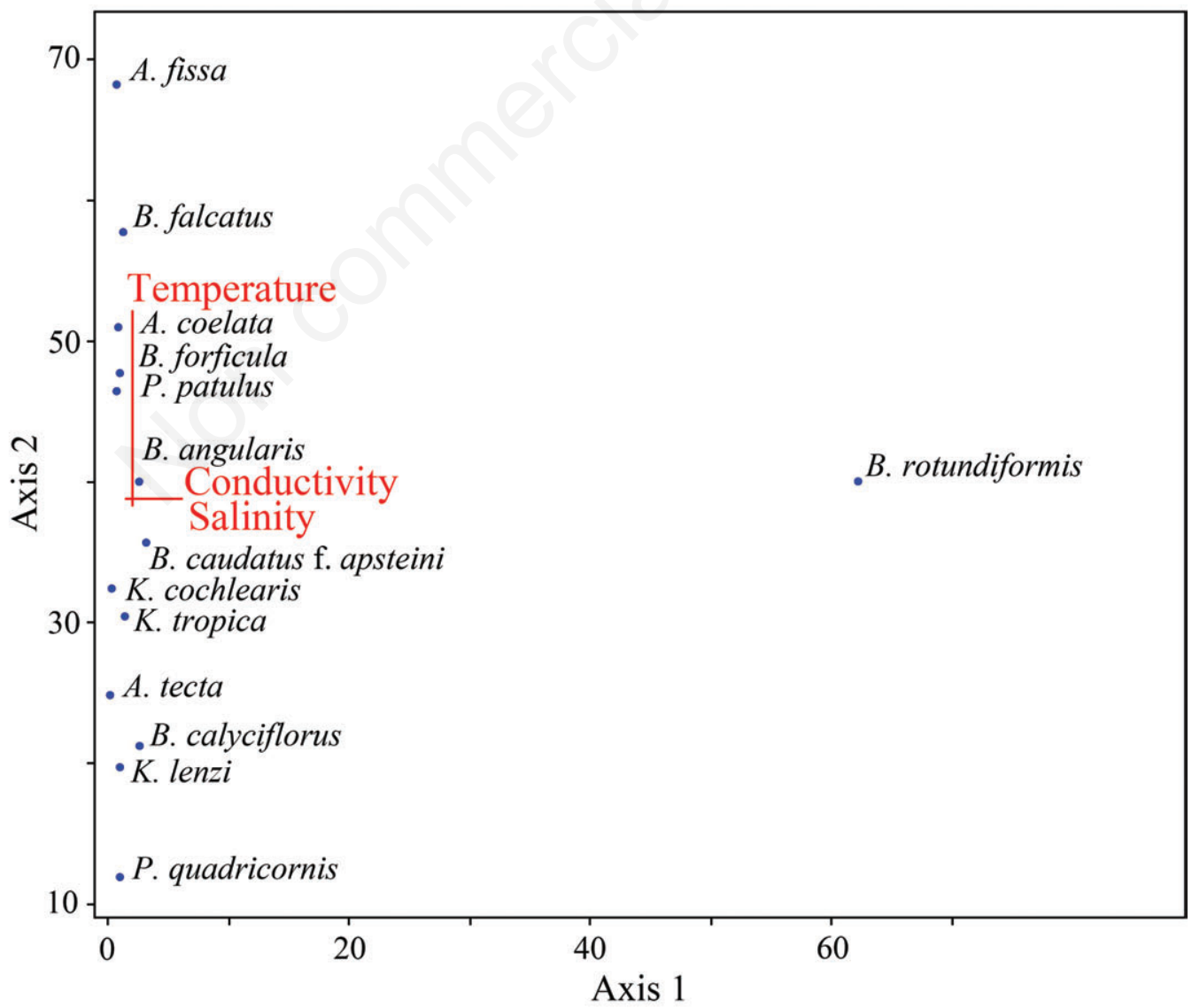

Fig. 2. Canonical correspondence analysis ordination of rotifer species and environmental variables. Species are represented by circles and environmental variables by lines. 
to have the same weight in their correlations with species data. Generally, salinity reflects the concentration of ions in the water, which can be measured in terms of electrical conductivity. Taxa that showed different affinities or tolerance to the three environmental variables were also determined (Fig. 2). Two species (Anuraeopsis fissa and B. falcatus) were positively correlated with temperature, while two species (Platyias quadricornis and K. lenzi) were negatively correlated with it. This result is in accordance with another report, in which A. fissa has been found in warmer water in New Zealand water bodies (Duggan et al., 2001). Also, Segers (2007) indicated that all Anuraeopsis species are warm water animals. Only one species, B. rotundiformis, was strongly positively correlated with conductivity and salinity while the other species were negatively correlated with these variables. Regarding habitat, low salinity values (0.04-2.73 PSU) were measured in some canals and a river locating in the central part of Thailand (i.e. Amphawa, Nakwang, and Sapandam canals, and Tha Chin river). This is a consequence of these canals and river being influenced by their closeness to the gulf of Thailand.

\section{Key to the recorded Thai brachionid rotifers}

Previous publications (Sanoamuang et al., 1995; Chittapun and Pholpunthin, 2001; Sanoamuang and Savatenalinton, 2001; Chittapun et al., 2002, 2007; Segers et al., 2004) and the present study of original material reveal that the Thai brachionid fauna consists of 37 species belonging to 5 genera. This includes Anuraeopsis (3 species), Brachionus (23 species), Keratella (9 species), Plationus (1 species) and Platyias (1 species). Keys to the genera and species of the Thai Brachionidae are provided below.
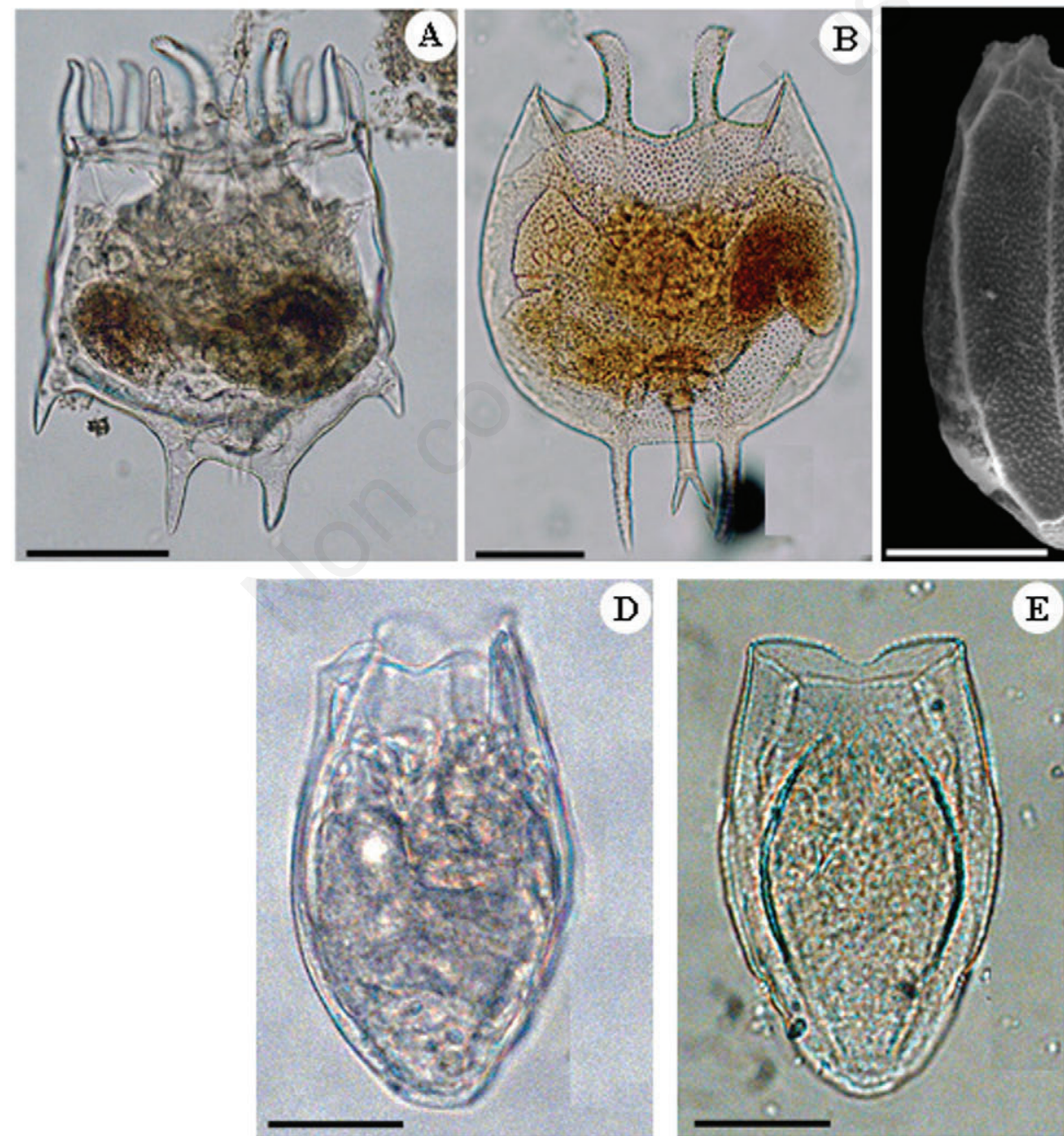

Fig. 3. A) Plationus patulus (Müller); B) Platyias quadricornis (Ehrenberg); C) Anuraeopsis coelata (De Beauchamp); D) A. fissa (Gosse); and E) A. navicula (Rousselet). Scale bars: A,B) $50 \mu \mathrm{m}$; C-E) $20 \mu \mathrm{m}$. 
Key to the genera of Brachionidae in Thailand

1. Foot present (in contracted material the foot may be completely retracted within the lorica. However, presence of a foot can always be ascertained by the relatively large foot opening in such specimens) ..........2

Foot absent........................................................4

2. Foot jointed (pseudosegmented), two toes ...............3

Foot annulated, retractile, two toes

Brachionus Pallas

3. Ventral head aperture with 4 spines, dorsal head aperture with six spines. Lorica asymmetrical

\section{Plationus Segers, Murugan and Dumont}

[(One species in Thailand, Plationus patulus (Müller)] (Fig. 3A)

Ventral head aperture without spines, dorsal with two spines

Platyias Harring

[(One species in Thailand, Platyias quadricornis (Ehrenberg)](Fig. 3B)

4. Dorsal plate with 6 anterior spines; 1,2 or no posterior spines Keratella Bory de St Vincent Lorica without spines; species relatively small

Anuraeopsis Lauterborn

\section{Genus Anuraeopsis Lauterborn}

This genus contains 10species, 3 of which (Anuraeopsis coelata, $A$. fissa and $A$. navicula) have been recorded from Thailand. The former two were found during the present study, the latter was recorded during previous studies only. In general, species are identified by means of body shape, shape of occipital edge of the lorica, surface pattern of lorica and body length. The description of the basic morphological structures of Anuraeopsis spp. was presented in Koste and Shiel (1987).

Key to the known species of genus Anuraeopsis Lauterborn in Thailand

1. Dorsal plate with double ridges connected in posterior third, lateral margin with facets (Fig. 3C)

A. coelata (De Beauchamp)

Dorsal plate without ridges and facets

2. Head aperture margin smooth, lorica oval shaped (Fig. 3D). A. fissa (Gosse)

Head aperture margin with fine serration, lorica navicula-shaped (Fig. 3E) A. navicula Rousselet
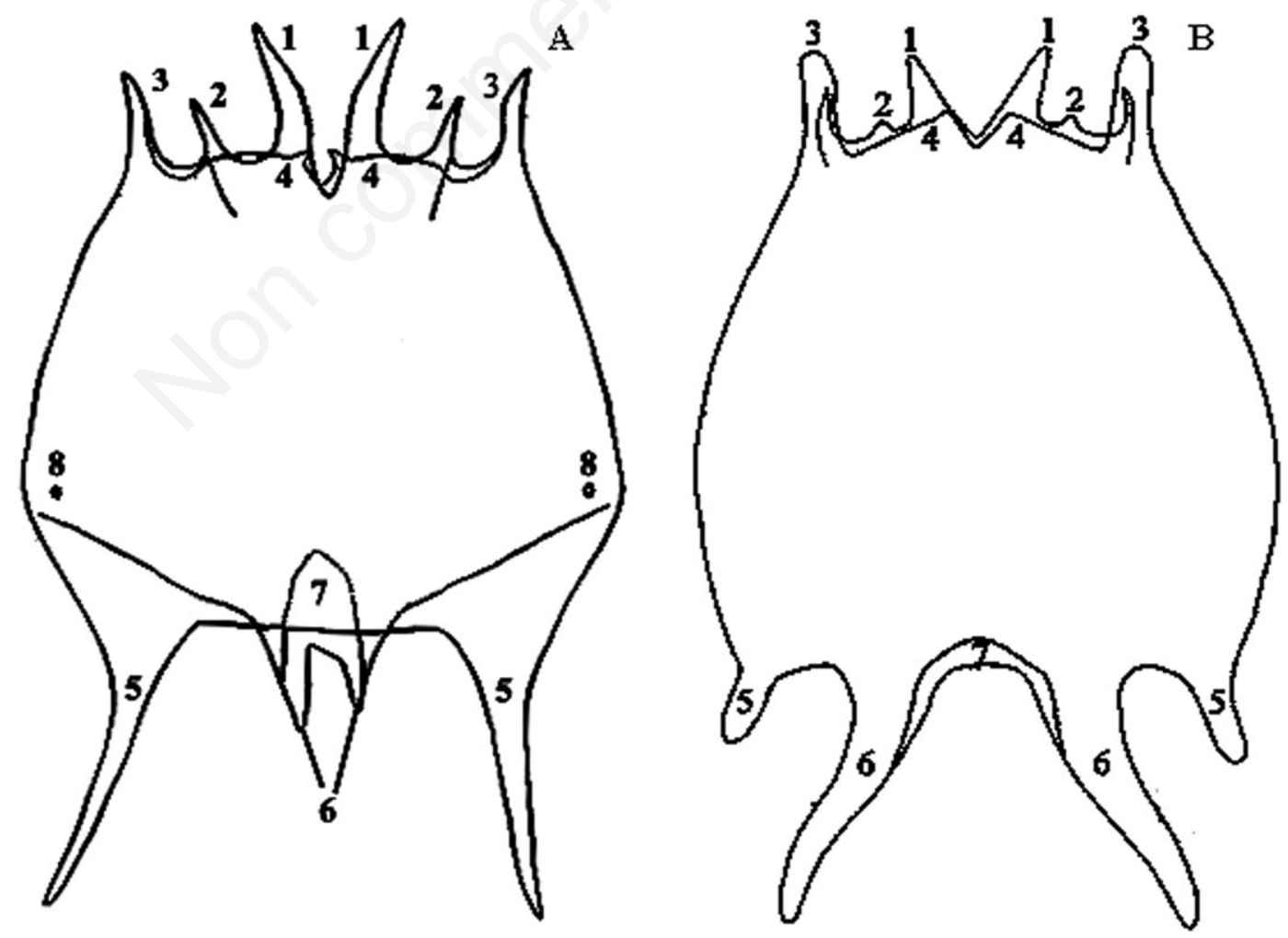

Fig. 4. Lorica of genus Brachionus: A) Brachionus quadridentatus Hermann and B) B. srisumonae Segers, Kotethip and Sanoamuang. 1, anterior median spines; 2, anterior intermediate spines; 3 , anterior lateral spines; 4, ventral anterior margin; 5, posterior lateral spines; 6 , spines of foot opening; 7 , foot opening; 8, lateral antennae. 

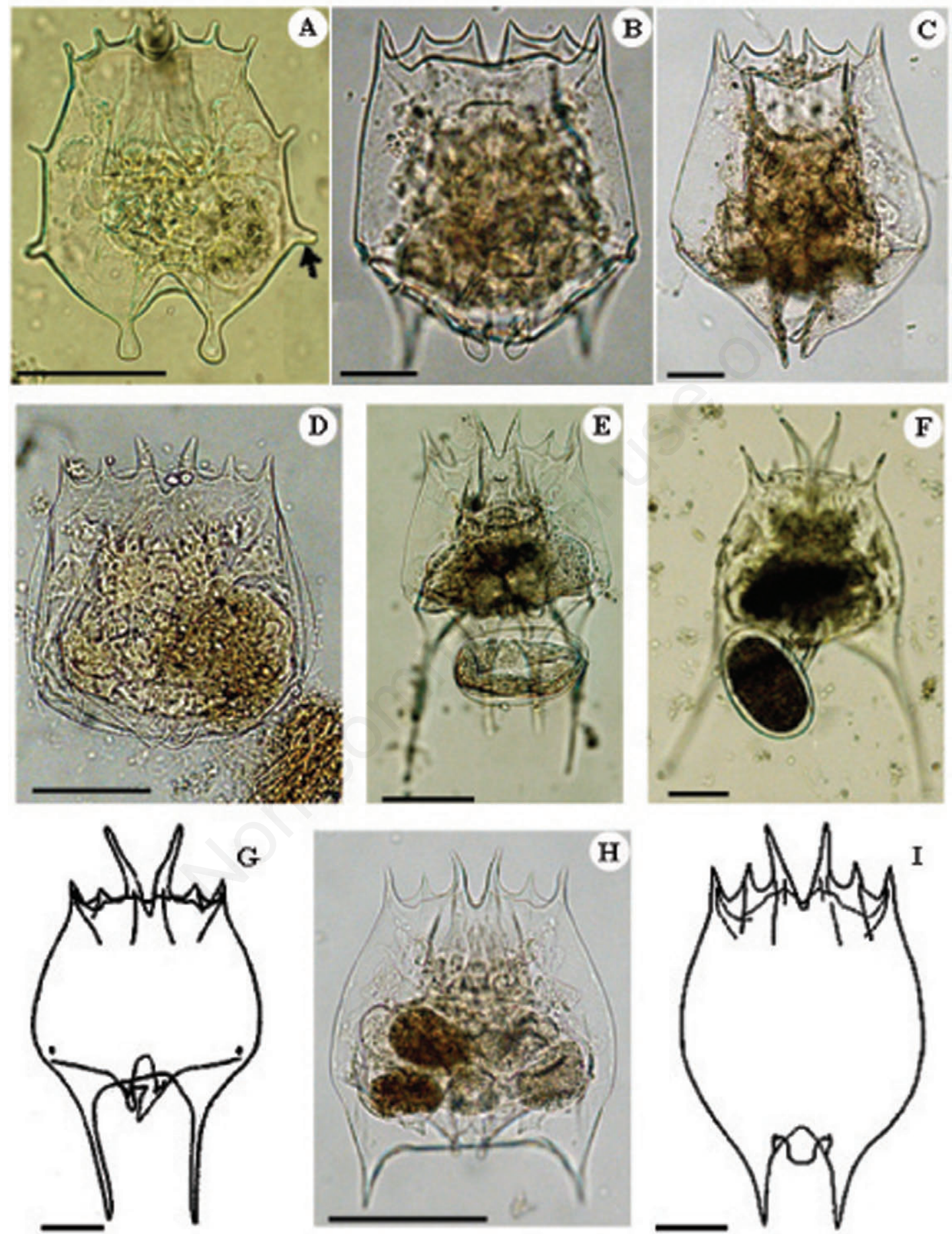

Fig. 5. A) Brachionus donneri Brehm; B) B. bidentatus f. bidentatus Anderson; C) B. bidentatus f. inermis (Rousselet); D) B. quadridentatus f. cluniorbicularis Skorikov; E) B. quadridentatus f. mirabilis (Daday); F) B. quadridentatus f. melhemi (Barrois and Daday); G) B. quadridentatus f. quadridentatus Hermann; H) B. quadridentatus f. brevispinus Ehrenberg; and I) B. variabilis Hempel. Scale bar: $50 \mu \mathrm{m}$. I) Modified after Ahlstrom (1940). 


\section{Genus Brachionus Pallas}

Brachionus is one of the first described genera of monogonont rotifers. The genus is considered cosmopolitan since its members can be found widely throughout all geographical regions of the world (Segers, 2007, 2008). It is a diverse group of brachionid rotifers spread both globally as well as in Thai water bodies. The various species can be identified by the number of anterior dorsal spines $(0,2,4$ and 6$)$, relative size and shape of anterior ventral spines, shape of ventral head aperture margin, position of foot aperture (terminal or ventral), shape of dorsal projection over foot aperture and special features. An overview of these features is presented in Fig. 4.

For the key to species, the publication presenting its description is given after the scientific name within parenthesis.

Key to the known species of genus Brachionus Pallas in Thailand

1. Dorsal anterior margin with six spines, median, intermediate and lateral spines present .............................2 Dorsal anterior margin with two or four spines, only median or median and lateral spines present ..........20

2. Lateral antennae on conical protuberance, ventral anterior margin with four rod-shaped spines (Fig. 5A)..

B. donneri Brehm (Koste and Shiel, 1987)

Lateral antennae not on conical protuberance, ventral anterior margin without spines

3. Sheath or tubular sheath surrounding foot opening..4 No definite foot sheath; foot aperture in same plane as lorica

4. Antero-lateral lorica spines longer than, or at least as long as, antero-middorsal spines ...5 Antero-middorsal lorica spines longer than antero-lateral spines

5. Postero-lateral spines present (Fig. 5B).....B. bidentatus f. Bidentatus Anderson (Plationus patulus will key out here if the retracted foot was misinterpreted as being annulated rather than pseudosegmented) (Kuczynski, 1991)

Postero-lateral spines absent (Fig. 5C)

\section{B. bidentatus $\mathrm{f}$. inermis (Rousselet)} .(Kuczynski, 1991)

6. Postero-lateral spines developed

Postero-lateral spines absent, posterior corners rounded (Fig. 5D).

B. quadridentatus

f. cluniorbicularis Skorikov

..(Koste and Shiel, 1987)

7. Foot opening spines rather short.....

Foot opening spines rather long, at least half as long as postero-lateral spines extending backward from the lorica, postero-lateral spines long, mostly divergent (Fig. 5E) B. quadridentatus f. mirabilis
(Daday) (Ahlstrom, 1940)

8. Postero-lateral spines parallel or convergent ............9 Postero-lateral spines rather long and divergent (Fig. $5 \mathrm{~F})$. B. quadridentatus f. melhemi (Barrois and Daday) (Koste and Shiel, 1987)

9. Median spines longest, 2-3 times longer than lateral spines; lorica relatively large (Fig. 5G)

..B. quadridentatus $\mathrm{f}$. quadridentatus

.Hermann (Ahlstrom, 1940)

Median spines slightly longer than lateral spines, postero-lateral spines of moderate length; lorica relatively small (Fig. 5H) .......B. quadridentatus f. brevispinus

Ehrenberg (Koste and Shiel, 1987)

10. Sub-squarish or tongue-shaped extension of dorsal plate overhanging foot opening (Fig. 5I).

..B. variabilis Hempel (Ahlstrom, 1940)

Sub-square extension over foot aperture absent ......11

11. Antero-lateral spines rod shaped, postero-lateral spines short and terminally bifid (Fig. 6A)..

..B. srisumonae Segers, Kotethip and

.Sanoamuang (Segers et al., 2004)

Antero-lateral spines acute at tip

12. Antero-intermediate spines longest, 3-5 times longer than median spines, spines of foot opening long (Fig. 6B)............. falcatus Zacharias (Kuczynski, 1991) Antero-intermediate spines not longest ...................13

13. Ventral anterior margin separated into four lobes or four blunt projections, living in saline water (Fig. 6C)

B. rotundiformis Tschugunoff .(Ciros-Pérez et al., 2001

Ventral anterior margin not separated into four lobes or projections ..14

14. Foot opening somewhat ventral, large and more or less round, intermediate spines rudimentary, sometimes epizoic on Cladocera (Fig. 6D) .......B. sessilis Varga

..(Koste and Shiel, 1987)

Foot opening terminal, free-swimming

15. Ventral head aperture margin smoothly undulated, with a median sinus, and two pairs of lobes set closely together, lorica relatively large (Fig. 6E) ...B. durgae

Dhanapathi (Dhanapathi, 1974) Ventral head aperture margin undulated, or with a single pair of projections and a central sinus ...............16

16. Lateral projections of the foot aperture diverging, convoluted, dorsal lorica with facets (Fig. 6F) ...B. kostei

..Shiel (Koste and Shiel, 1987) Lateral projections of the foot aperture absent or rudi-

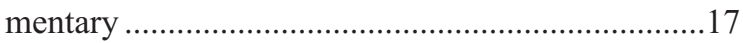

17. Lorica with a pattern of wavy lines ..........................18 Lorica usually lightly stippled ..................................19

18. Lorica truncate posteriorly in lateral view (Fig. 6GH)........... B. bennini (Leissling) (Ahlstrom, 1940) Lorica pointed posteriorly in lateral view (Fig. 6I-J) . B. urceolaris (Müller) (Ahlstrom, 1940) 

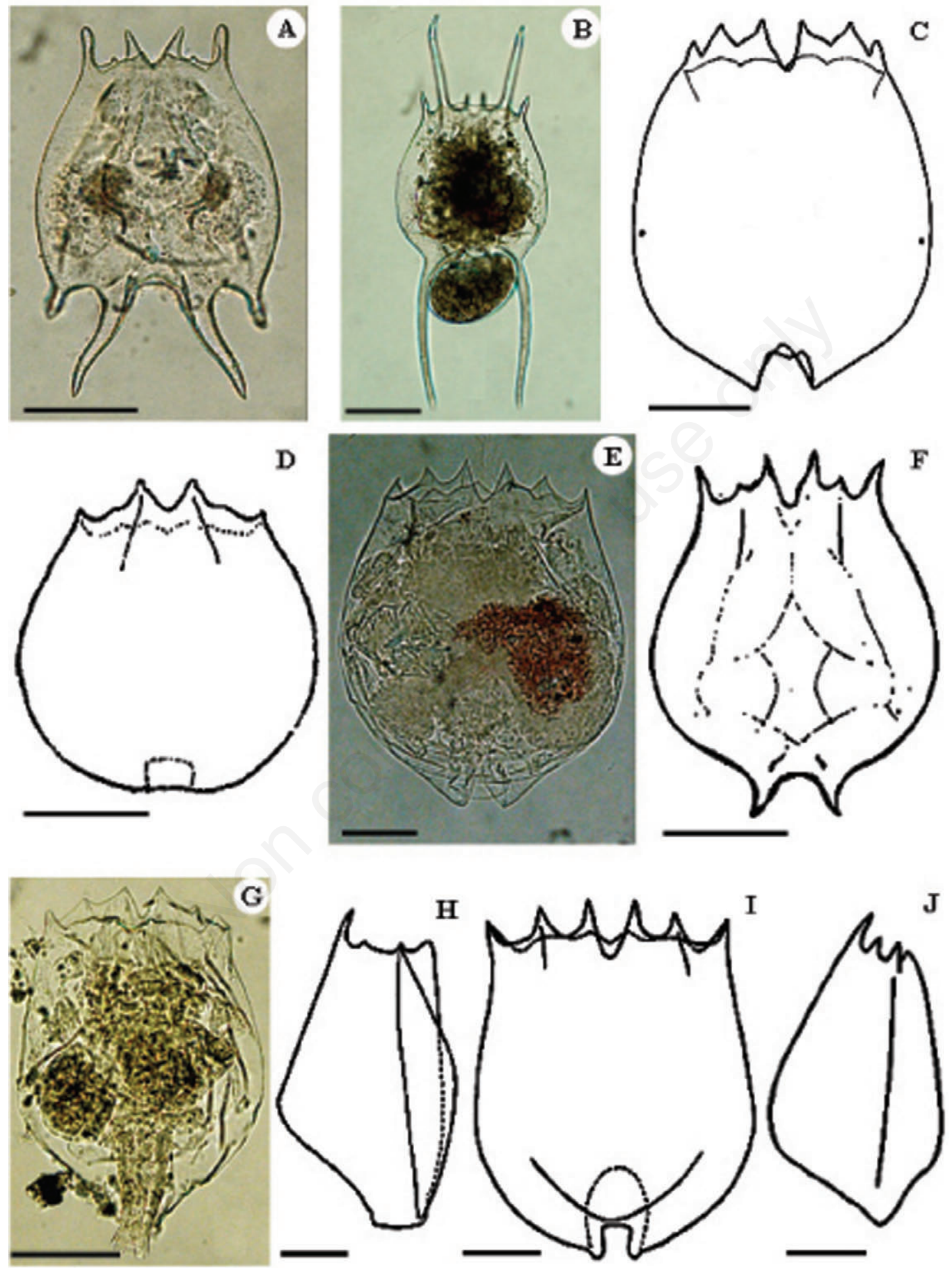

Fig. 6. A) Brachionus srisumonae Segers, Kotethip and Sanoamuang; B) B. falcatus Zacharias; C) B. rotundiformis Tschugunoff; D) B. sessilis Varga; E) B. durgae Dhanapathi; F) B. kostei Shiel; G,H) B. bennini (Leissling); G) ventral view; H) lateral view; I,J) B. urceolaris (Müller), I) dorsal view, and J) lateral view. Scale bar: $50 \mu \mathrm{m}$. D-F) Modified after Koste and Shiel (1987) and H-J) after Ahlstrom (1940). 

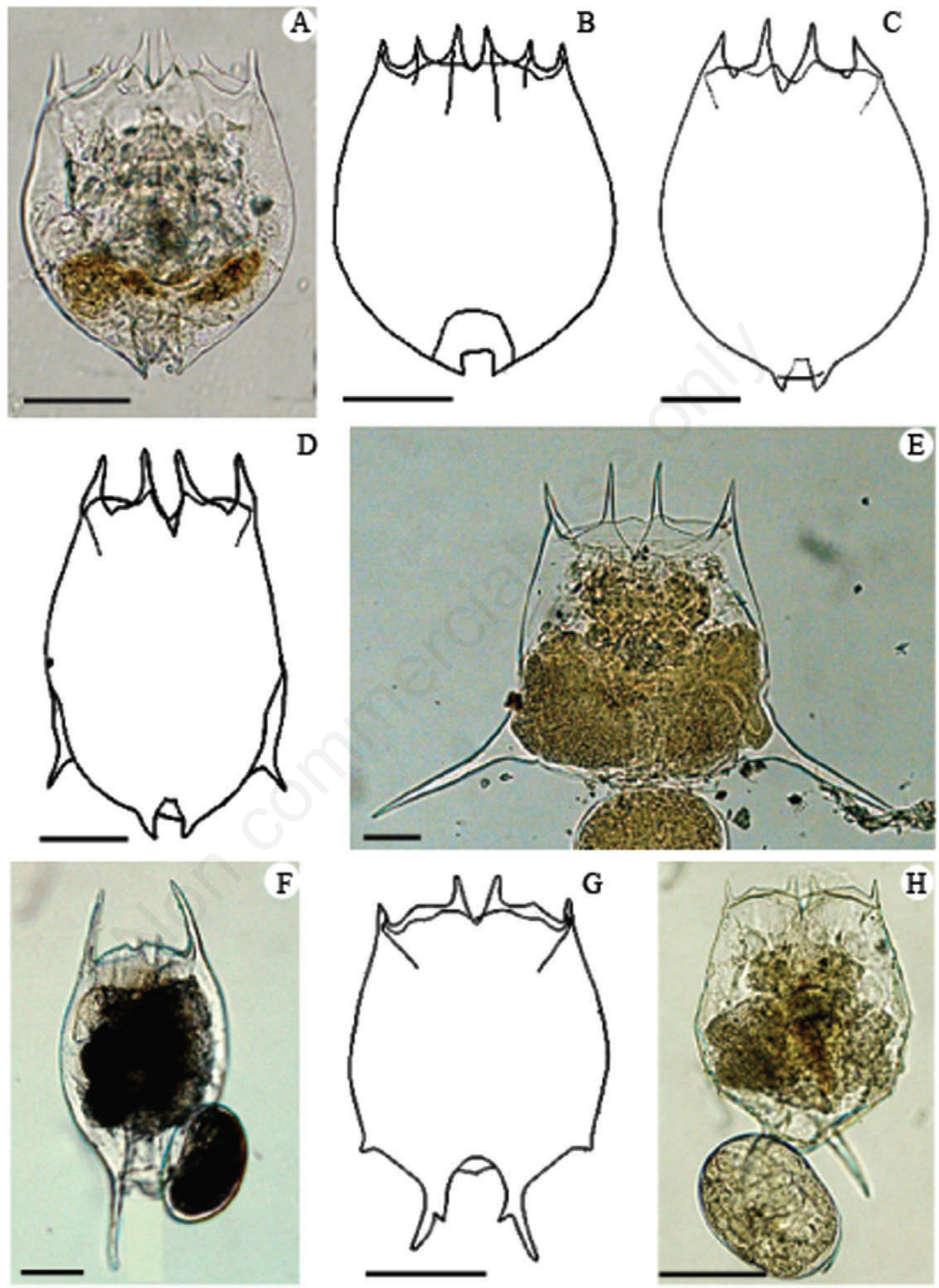

Fig. 7. A) Brachionus rubens Ehrenberg; B) B. nilsoni Ahlstrom; C) B. calyciflorus f. calyciflorus Pallas; D) B. calyciflorus f. anuraeiformis Brehm; E) B. calyciflorus f. amphiceros Ehrenberg; F) B. diversicornis (Daday); G) B. caudatus f. aculeatus Hauer; H) B. caudatus f. apsteini Fadeew. Scale bars: $50 \mu \mathrm{m}$. 
19. Median and intermediate spines showing a narrow anterior part, rounding outward and forming a broad base. Ventral foot aperture nearly parallel-sided (Fig. 7A).............B. rubens Ehrenberg (Ahlstrom, 1940) Median and intermediate spines thin, acutely pointed. Ventral foot aperture large, with diverging lateral margins (Fig. 7B) B. nilsoni Ahlstrom (Ahlstrom, 1940)

20. Anterior dorsal margin with 4 spines, median and lat-

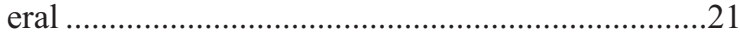

Anterior dorsal margin with 2 well-developed spines, median; if present, intermediate and/or lateral rudimentary .30

21. Lorica indistinctly separated into dorsal and ventral plates, anterior dorsal spines elongate, with broad basis . .22 Lorica with clear dorsal and ventral plates, lateral margins sharp.... .24

22. Postero-lateral spines developed, anterior spines more or less equal. .23 Postero-lateral spines absent, antero-dorsal median spines longer than antero- lateral spines (Fig. 7C) .....

B. calyciflorus f. calyciflorus Pallas

(Ahlstrom, 1940)

23. Postero-lateral spines short (22-46 mm) (Fig. 7D) .... B. calyciflorus f. anuraeiformis Brehm

(Kuczynski, 1991)

Postero-lateral spines very long (127-195 mm) (Fig. 7E)............ calyciflorus f. amphiceros Ehrenberg

..(Kuczynski, 1991)

24. Antero-lateral spines much longer than median spines, foot opening spines close together at their point of origin (Fig. 7F) B. diversicornis (Daday) (Ahlstrom, 1940) Antero-median spines longer than lateral spines or these spines are of about equal length ...................25

25. Foot opening spines present ...............................26

Foot opening spines absent ...............................29

26. Extension of dorsal plate overhanging foot opening, posterior spines quite close together.....................27 No extension of dorsal plate over foot opening, foot opening spines wide apart at base, and with knee-like swellings on inner side .28

27. An accessory spur-like spine arising from inner dorsal side of each foot opening spine (Fig. 7G)

...B. caudatus f. aculeatus Hauer (Ahlstrom, 1940) Accessory spine not developed, foot opening spines smooth (Fig. 7H)......B. caudatus f. apsteini Fadeew

(Ahlstrom, 1940)

28. Lorica relatively large, foot opening spines equal in length (Fig. 8A).B. forficula f. forficula Wierzejski

(Ahlstrom, 1940)

Lorica relatively small, foot opening spines relatively short, sometimes asymmetrical (Fig. 8B)....

B. forficula f. minor Voronkov
(Koste and Shiel, 1987)

29. Equal antero-dorsal spines, lateral spines straight, lorica firm with cuticular ridges (Fig. 8C).

B. budapestinensis Daday (Ahlstrom, 1940) Unequal antero-dorsal spines, lateral spines directed outwards, lorica relatively soft (Fig. 8D)

B. murphyi Sudzuki (Sudzuki, 1989)

30. Antero median spines long, foot opening spines long ..31

Antero median spines short, foot opening spines short or absent............................................................ 32

31. Lorica oval-shaped antero intermediate spines absent, but antero lateral short (Fig. 8E) ............B. caudatus ...f. caudatus Barrois and Daday (Ahlstrom, 1940) Lorica pear-shaped antero intermediate spines short, but antero lateral absent (Fig. 8F).......B. dichotomus f. reductus Koste and Shiel (Koste and Shiel, 1980)

32. Foot opening with spines lyre-shaped, antero intermediate and lateral spines of lorica rudimentary (Fig. 8G)

B. lyratus Shephard (Koste and Shiel, 1980) Foot opening spines, if present, not lyre-shaped, antero intermediate and lateral spines of lorica absent......33

33. Small but sharp, pointed lateral projections of the foot aperture present (Fig. 8H)

B. angularis

f. bidens Plate (Ahlstrom, 1940)

Pointed lateral projections of the foot aperture absent, if present, rudimentary (Fig. 8I)

B. angularis

..f. angularis Gosse (Ahlstrom, 1940)

\section{Genus Keratella Bory de St Vincent}

Nine species have been recorded in Thailand. One of them ( $K$. taksinensis) is endemic to the country. Species are identified based upon the following characters: number of anterior spines, position of posterior spine(s) and pattern of facets on the dorsal lorica.

For the key to species, the publication presenting its description is given after the scientific name within parenthesis.

Key to the known species of genus Keratella Bory de St. Vincent in Thailand

1. Dorsal plate with median ridge ............................. 2 Dorsal plate without median ridge........................... 3

2. Posterior spine always present, pointed slightly ventrally; species relatively large, (Fig. 9A)

K. cochlearis (Gosse) (Ahlstrom, 1943)

Posterior spine generally absent, when present, short and sharply set-off from the lorica, held in body axis; species relatively small; anterior spines mostly relatively short, (Fig. 9B) .... K. tecta (Gosse) .(Ahlstrom, 1943)

3. Central row of facets present .................................4 Central facets not in a row but as an irregular group 

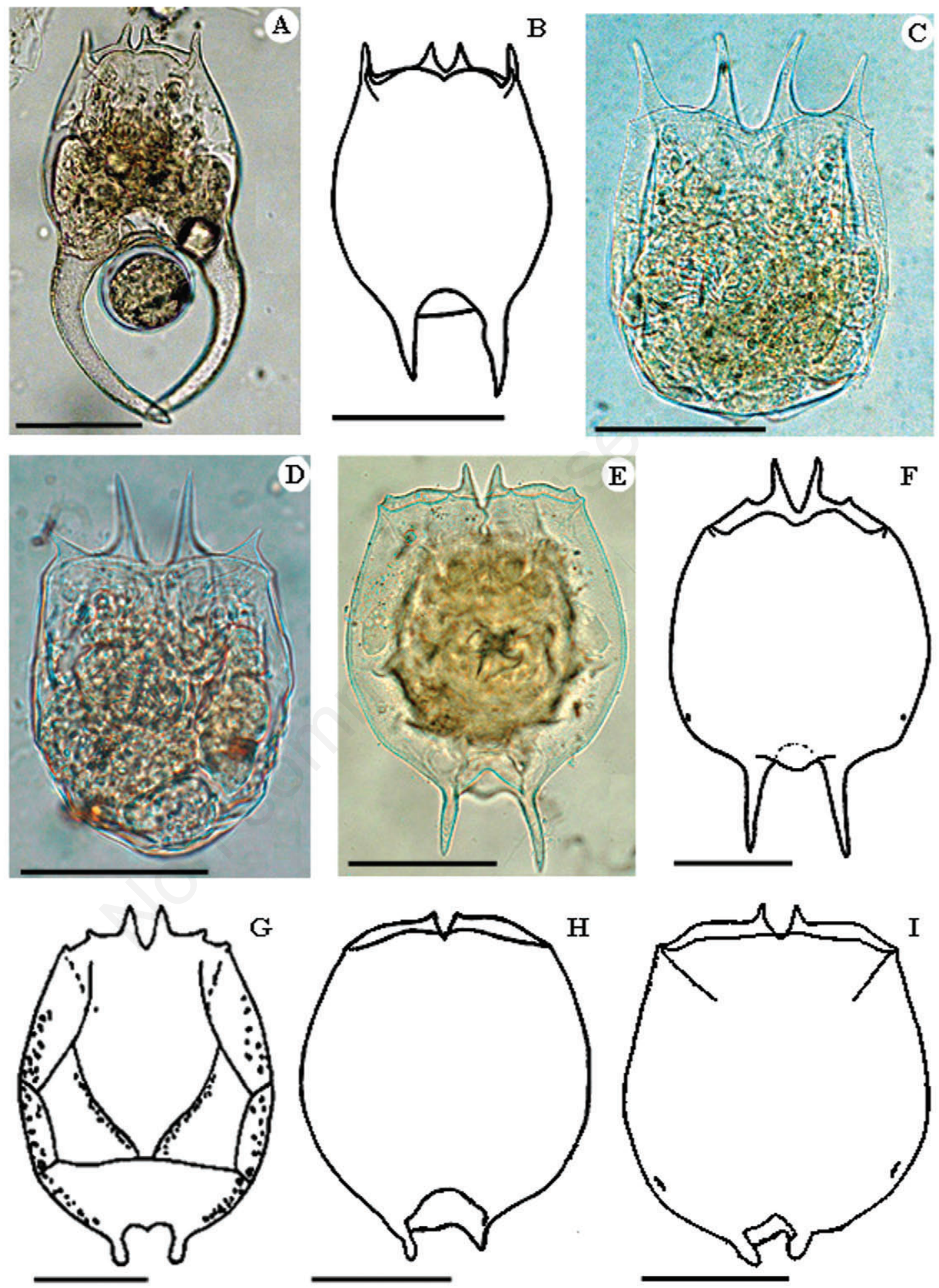

Fig. 8. A) Brachionus forficula f. forficula Wierzejski; B) B. forficula f. minor Voronkov; C) B. budapestinensis Daday; D) B. murphyi Sudzuki; E) B. caudatus f. caudatus Barrois and Daday; F) B. dichotomus f. reductus Koste and Shiel; G) B. lyratus Shephard; H) B. angularis f. bidens Plate; I) B. angularis f. angularis Gosse. Scale bar: $50 \mu \mathrm{m}$. G) Modified after Koste and Shiel (1987). 

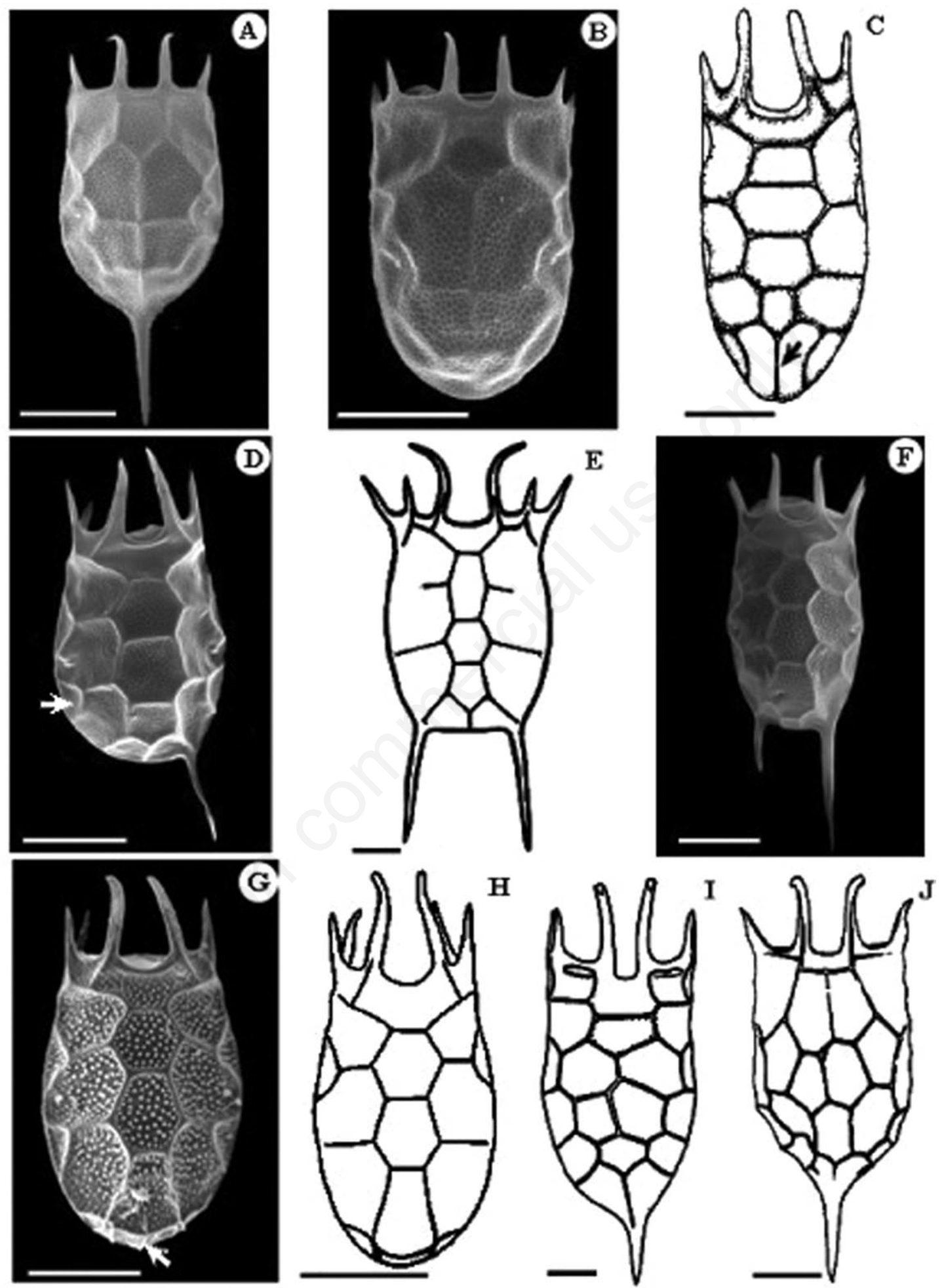

Fig. 9. A) Keratella cochlearis (Gosse); B) K. tecta (Gosse); C) K. taksinensis Chitapun, Pholpunthin and Segers; D) K. procurva (Thorpe); E) K. edmondsoni Ahlstrom; F) K. tropica (Apstein); G) K. lenzi f. heliaca Bērziņš; H) K. lenzi Hauer; I) K. mixta (OparinaCharitonova); J) K. javana Hauer. Scale bar: $30 \mu \mathrm{m}$. C) Modified after Chittapun et al. (2002); I) after Ahlstrom (1943); J) after Koste and Shiel (1987). Arrowheads in C,D) and G) indicate median line, marginal plaque and short median ridge, respectively. 
of facets.

4. Posterior median facet terminates in a short median line .5

Posterior median facet does not terminate in a median line . .7

5. Median row of facets consists of three enclosed facets Median row of facets consists of four enclosed facets (Fig. 9C).....K. taksinensis Chittapun, Pholpunthin and Segers (Chittapun et al., 2002)

6. Marginal plaques present, posterior spines asymmetric and straight (Fig. 9D)..... K. procurva (Thorpe) ...(Ahlstrom, 1943) Marginal plaques absent, posterior spines symmetric and characteristically bent (Fig. 9E) ..K. edmondsoni Ahlstrom (Ahlstrom, 1943)

7. Lorica posteriorly with terminal row of minute facets; no posterior spines. Lorica with a small, median posterior facet; lorica mostly with asymmetrical posterior spines (Fig. 9F) .

K. tropica (Apstein) (Ahlstrom, 1943)

8. Short median ridge near the terminal end of the lorica present (Fig. 9G)

.K. lenzi f. heliaca Bērziņš .(Koste and Shiel, 1987)

Short median ridge near the terminal end of the lorica absent (Fig. 9H). K. lenzi Hauer ..(Koste and Shiel, 1987)

9. Dorsal plate with six enclosed central facets (Fig. 9I) ..K. mixta (Oparina-Charitonova) ...(Ahlstrom, 1943) Dorsal plate with nine enclosed central facets (Fig. 9J) .K. javana Hauer (Ahlstrom, 1943)

\section{CONCLUSIONS}

Previous publications and the present study reveal that the Thai brachionid fauna consists of 49 taxa, 37 species and 12 infrasubspecific forms. This paper developed keys to the genera and species. In addition to this, useful taxonomic characters were identified as being: type of foot, the number of occipital spines, relative size and shape of occipital spines, shape of occipital edge of the lorica, surface pattern on the dorsal lorica, general body shape, position of posterior spine, position of foot aperture and shape of dorsal projection over foot aperture. In future taxonomic works, we suggest investigating external morphology together with trophi structure, one of the most useful taxonomic characters, and using molecular tools to solve the taxonomic problems in some species-groups (e.g. B. caudatus and B. quadridentatus groups).

\section{ACKNOWLEDGMENTS}

This work was supported by the Royal Golden Jubilee $\mathrm{PhD}$ Program No. PHD/0218/2545, and the National Re- search University Project of Thailand, Office of the Higher Education Commission, through the Holistic Watershed Management Cluster of Khon Kaen University. We thank Dr. Niwat Sanoamuang and Dr. Jittra Teeramaethee for field assistance. Dr. Jolyon Dodgson is thanked for his help with the English corrections.

\section{REFERENCES}

Ahlstrom EH, 1940. A revision of the rotatorian genera Brachionus and Platyias with descriptions of one new species and two new varieties. B. Am. Mus. Nat. Hist. 77:143-184.

Ahlstrom EH, 1943. A revision of the rotatorian genus Keratella with descriptions of three new species and five new varieties. B. Am. Mus. Nat. Hist. 80:411-457.

Attayde JL, Bozelli RL, 1998. Assessing the indicator properties of zooplankton assemblages to disturbance gradients by canonical correspondence analysis. Can. J. Fish. Aquat. Sci. 55:1789-1797.

Bielanska-Grajner I, 1995. Influence of temperature on morphological variation in populations of Keratella cochlearis (Gosse) in Rybnik Reservoir. Hydrobiologia 313/314:139-146.

Boonsom J, 1984. The freshwater zooplankton of Thailand (Rotifera and Crustacea). Hydrobiologia 113:223-229.

Chittapun S, Pholpunthin P, 2001. The rotifer fauna of peatswamps in southern Thailand. Hydrobiologia 446/447:255259.

Chittapun S, Pholpunthin P, Segers H, 2002. Rotifer diversity in a peat-swamp in southern Thailand (Narathiwas province) with the description of a new species of Keratella Bory de St. Vincent. Ann. Limnol.-Int. J. Lim. 38:185-190.

Chittapun S, Pholpunthin P, Segers H, 2007. Diversity of rotifer fauna from five coastal peat swamps on Phuket Island, Southern Thailand. ScienceAsia 33:383-387.

Ciros-Pérez J, Gómez A, Serra M, 2001. On the taxonomy of three sympatric sibling species of the Brachionus plicatilis (Rotifera) complex from Spain, with the description of $B$. ibericus n. sp. J. Plankton Res. 23:1311-1328.

Dhanapathi MVSSS, 1974. Rotifers from Andhra Pradesh, India, I. Hydrobiologia 45:357-372.

Duggan IC, Green JD, Shiel RJ, 2001. Distribution of rotifers in North Island, New Zealand, and their potential use as bioindicators of lake trophic state. Hydrobiologia 446/447:155-164.

Fontaneto D, De Smet WH, Melone G, 2008. Identification key to the genera of marine rotifers worldwide. Meiofauna Marina 16:75-99.

Gilbert JJ, Walsh EJ, 2005. Brachionus calyciflorus is a species complex: mating behavior and genetic differentiation among four geographically isolated strains. Hydrobiologia 546:257265.

Hofmann W, 1980. On morphological variation in Keratella cochlearis populations from Holstein lakes (Northern Germany). Hydrobiologia 73:255-258.

Kaya M, Fontaneto D, Segers H, Altindağ A, 2010. Temperature and salinity as interacting drivers of species richness of planktonic rotifers in Turkish continental waters. J. Limnol. 69:297-304

Koste W, 1978. [Rotatoria Die Rädertiere Mitteleuropas]. [Book in German]. Borntraeger, Berlin: 673 pp. 
Koste W, Shiel RJ, 1987. Rotifera from Australian inland waters. II. Epiphanidae and Brachionidae (Rotifera: Monogononta). Invertebr. Taxon. 7:949-1021.

Kuczynski D, 1991. Rotifers from Reconquista River, Argentina: the genus Brachionus with descriptions of new species. Hydrobiologia 215:135-152.

LubzensE, Zmora O, Barr Y, 2001. Biotechnology and aquaculture of rotifers. Hydrobiologia 446/447:337-353.

Marinone M, Zagarese H, 1991. A field and laboratory study on factors affecting polymorphism in the rotifer Keratella tropica. Oecologia 86:372-377.

Nogrady T, Wallace RL, Snell TW, 1993. Rotifera, 1: biology, ecology and systematics. guides to the identification of the microinvertebrates of the continental waters of the world 4.SPB Academic Publ., The Hague: 142 pp.

Pejler B, Bērziņš B, 1989. On choice of substrate and habitat in brachionid rotifers. Hydrobiologia 186/187:137-144.

Ruttner-Kolisko A, 1974. Planktonic rotifers: biology and taxonomy. Freshwater Ecol. 26:1-146.

Sanoamuang L, McKenzie JC, 1993. A simplified method for preparing rotifer trophi for scanning electron microscopy. Hydrobiologia 250:91-95.

Sanoamuang L, Savatenalinton S, 2001. The rotifer fauna of Lake Kud-Thing, a shallow lake in Nong Khai Province, northeast Thailand. Hydrobiologia 446/447:297-304.

Sanoamuang L, Segers H, Dumont HJ, 1995. Additions to the rotifer fauna of south-east Asia: new and rare species from north-east Thailand. Hydrobiologia 313/314:35-45.

Segers H, 1993. Rotifera of some lakes in the floodplain of the river Niger (Imo State, Nigeria). I. New species and other taxonomic considerations. Hydrobiologia 250:39-61.

Segers H, 1995. Nomenclatural consequences of some recent studies on Brachionus plicatilis (Rotifera, Brachionidae). Hydrobiologia 313/314:121-122.

Segers H, 2001. Zoogeography of the Southeast Asian Rotifera. Hydrobiologia 446/447:233-246.

Segers H, 2007. Annotated checklist of the rotifers (Phylum Ro- tifera) with notes on nomenclature, taxonomy and distribution. Zootaxa 1564:1-104.

Segers H, 2008. Global diversity of rotifers (Rotifera) in freshwater. Hydrobiologia 595:49-59.

Segers H, De Smet WH, 2008. Diversity and endemism in Rotifera: a review, and Keratella Bory de St Vincent. Biodivers. Conserv. 17:303-316.

Segers H, Dumont HJ, 1993. Rotifera from Arabia, with descriptions of two new species. Fauna Saudi Arabia 13:3-26.

Segers H, Kotethip W, Sanoamuang L, 2004. Biodiversity of freshwater microfauna in the floodplain of the river Mun, Northeast Thailand: the Rotifera monogononta. Hydrobiologia 515:1-9.

Silva-Briano M, Galván-De la Rosa R, Alejandro Pérez-Legaspi I, Rico-Martínez R, 2007. On the description of Brachionus araceliae sp. nov. A new species of freshwater rotifer from Mexico. Hydrobiológica 17:179-183.

Sladecek V, 1983. Rotifer as indicators of water quality. Hydrobiologia 100:169-201.

Snell TW, Janssen CR, 1995. Rotifers in ecotoxicology: a review. Hydrobiologia 313/314:231-247.

Sudzuki M, 1989. Rotifera from the Oriental region and their characteristics. Special Issue celebrating the Centennial Anniversary of the Foundation of Nihon Daigaku University. Nihon Daigaku University ed., Tokyo: 338 pp.

Xiang XL, Xi YL, Wen XL, Zhang G, Wang JX, Hu K, 2011a. Genetic differentiation and phylogeographical structure of the Brachionus calyciflorus complex in eastern China. Mol. Ecol. 20:3027-3044.

Xiang XL, Xi YL, Wen XL, Zhang G, Wang JX, Hu K, 2011 b. Patterns and processes in the genetic differentiation of the Brachionus calyciflorus complex, a passively dispersing freshwater zooplankton. Mol. Phylogenet. Evol. 59:386-398.

Xiang XL, Xi YL, Wen XL, Zhang JY, Ma Q, 2010. Spatial patterns of genetic differentiation in Brachionus calyciflorus species complex collected from East China in summer. Hydrobiologia 638:67-83. 